\title{
ANALISIS TINGKAT KEBISINGAN PADA DEPARTEMENT FIBER LINE DI PT. TOBA PULP LESTARI
}

\author{
Cut Ita Erliana ${ }^{1}$, Defi Irwansyah ${ }^{1}$, Dahlan Abdullah ${ }^{2}$, Muhammad Zarlis ${ }^{3}$, \\ Elviwani $^{4}$ \\ ${ }^{1}$ Program Studi Teknik Industri, Universitas Malikussaleh, Aceh, Indonesia \\ 2 Program Studi Teknik Informatika, Universitas Malikussaleh, Aceh, Indonesia \\ 3,4 Program Studi Ilmu Komputer, Universitas Sumatera Utara, Medan, Indonesia \\ ${ }^{1}$ cutitha@unimal.ac.id,2dahlan@unimal.ac.id, ${ }^{3}$ mzarlis2000@yahoo.com, \\ 4elviwani@usu.ac.id
}

\begin{abstract}
ABSTRAK
Tenaga kerja merupakan unsur dominan yang mengelola bahan baku, mesin, peralatan dan proses lainnya yang dilakukan di tempat kerja, guna menghasilkan suatu produk yang bermanfaat bagi masyarakat. Selain itu, tenaga kerja merupakan unsur yang berhadapan langsung dengan berbagai akibat dari kegiatan industri yang dilakukan. Lingkungan kerja fisik yang tidak memenuhi syarat seperti bising yang telah melebihi NAB merupakan salah satu contoh yang dihadapi oleh tenaga kerja di lingkungan kerja. Salah satu kegiatan yang menghasilkan bising adalah kegiatan pada departement fiberline di PT. Toba Pulp Lestari yang merupakan area pembuatan pulp. Kebisingan yang ditimbulkan dari mesin-mesin produksi menimbulkan sulitnya berkomunikasi antara sesama karyawan dan mengganggu sistem pendengaran sehingga meningkatkan kelelahan kerja pada karyawan. Penelitian ini bertujuan untuk mengetahui pengaruh kebisingan terhadap kelelahan kerja pada karyawan. Pengukuran kebisingan dilakukan di 30 titik pengukuran. Pemetaan kebisingan (noise mapping) digunakan untuk melihat daerahdaerah yang bising ataupun daeah yang tidak bising. Regresi linear digunakan untuk mengetahui pengaruh antara kebisingan dan kelelahan kerja yang dialami oleh karyawan. Korelasi digunakan untuk mengetahui seberapa kuat hubungan antara kebisingan dan kelelahan. Hasil dari regresi menunjukkan semakin tinggi tingkat kebisingan maka semakin tinggi pula tingkat kelelahan kerja pada karyawan. Hasil dari analisis korelasi diketahui bahwa korelasi bernilai positif atau berkorelasi
\end{abstract}


kuat. Ini menunjukkan bahwa pengaruh kebisingan terhadap kelelahan sangat kuat.

Kata kunci: Fiber Line, Kebisingan, Kelelahan, Pemetaan Kebisingan

\section{PENDAHULUAN}

Seiring dengan perkembangan zaman atau di era globalisasi teknologi dibidang industri semakin canggih dan berkembang. Berbagai kegiatan masyarakat baik yang disadari ataupun tidak disadari dapat menimbulkan sumber kebisingan dengan tingkat intensitas yang berbeda. Hal ini diakibatkan oleh kebutuhan masyarakat yang semakin meningkat. Manusia membutuhkan industri untuk memenuhi kebutuhan hidupnya. Namun kebanyakan aktivitas dalam suatu industri terutama proses produksi, dapat menimbulkan kebisingan yang dapat mengganggu tenaga kerja yang biasa terpapar dengan sumber kebisingan secara khusus maupun masyarakat sekitarnya secara umum.

Kebisingan merupakan sebuah bentuk energi yang bila tidak disalurkan pada tempatnya akan berdampak serius bagi kesehatan manusia dan lingkungan. Upaya pengawasan dan pengendalian kebisingan menjadi faktor yang menentukan kualifikasi suatu perusahaan dalam menangani masalah lingkungan yang muncul. Kebisingan merupakan salah satu aspek lingkungan yang perlu diperhatikan.

Kebisingan yang melebihi standar dapat berakibat buruk terhadap manusia, seperti menggangu kenyamanan, penurunan ketajaman pendengaran sampai tuli, terganggunya sistem keseimbangan, gangguan konsentrasi, meningkatkan kadar emosi dan juga dapat mengganggu sistem metabolisme tubuh. Hingga saat ini kebisingan pada kegiatan industri belum banyak diperhatikan terutama industri di Indonesia. Hal ini tercermin dari sedikitnya penelitian-penelitian mengenai kebisingan dan masih kurangnya perhatian pihak pengusaha industri serta kurangnya kesadaran para tenaga kerja akan pengaruh kebisingan di lingkungan pabrik.

PT. Toba Pulp Lestari merupakan salah satu perusahaan yang bergerak dalam pembuatan serat rayon (viscose rayon). Dalam menunjang proses produksi guna memenuhi tuntutan peningkatan produktivitas dan penurunan tenaga kerja maka pihak PT. Toba Pulp Lestari menerapkan sistem mekanisasi pada alat dan mesin produksi, sehingga 
diharapkan dapat meningkatkan produktivitas serat rayon (viscose rayon) guna memenuhi permintaan pasar.

Salah satu kegiatan yang menghasilkan kebisingan pada PT Toba Pulp Lestari adalah kegiatan pada Department Fiber Line. Fibe Line merupakan area pembuatan serat rayon (viscose rayon). Department ini memiliki 4 area, yaitu digester, washing, bleaching dan pulp machine. Kebisingan yang ditimbulkan dari mesin-mesin yang beroperasi menimbulkan sulitnya berkomunikasi antara sesama karyawan dan akan mengganggu sistem pendengaran sehingga menurunkan performansi dan produktivitas tenaga kerja.

\section{METODOLOGI PENELITIAN}

Metode yang digunakan dalam penelitian ini adalah Regresi Linier, dimana pemetaan kebisingan (noise mapping) digunakan untuk melihat daerah-daerah yang bising ataupun daeah yang tidak bising. Regresi linear digunakan untuk mengetahui pengaruh antara kebisingan dan kelelahan kerja yang dialami oleh karyawan. Korelasi digunakan untuk mengetahui seberapa kuat hubungan antara kebisingan dan kelelahan

\section{HASIL DAN PEMBAHASAN}

Pengukuran tingkat kebisingan pada departement fiberline dilakukan di 30 titik pengukuran dengan menggunakan alat ukur kebisingan Sound Level Meter (SLM) selama 14 jam dengan waktu pengukuran yang telah ditentukan. Rentang waktu pengukuran selama 5 hari. Adapun data pengukuran kebisingan pada hari pertama dapat dilihat pada Tabel 1.

Tabel 1. Hasil Pengukuran Kebisingan

Hari Ke-1

\begin{tabular}{|c|c|c|c|c|c|c|c|}
\hline \multirow{3}{*}{ Titik } & \multirow{2}{*}{\multicolumn{6}{|c|}{ Tingkat Kebisingan $(d B A$ ) }} & \multirow{3}{*}{ Lokas } \\
\hline & & & & & \\
\hline & 09:00 & 11:00 & 13:00 & $15: 00$ & $17: 00$ & $21: 00$ & \\
\hline 1 & 87,9 & 88 & 88,5 & 87,8 & 86,4 & 85,1 & \multirow{8}{*}{ 密 } \\
\hline 2 & 87,5 & 88,6 & 87,9 & 87,9 & 87,3 & 87,8 & \\
\hline 3 & 87,7 & 87,3 & 38,5 & 87,9 & 87,2 & 87,3 & \\
\hline 4 & 86,9 & 87,7 & 38,6 & 88,5 & 86,6 & 87,7 & \\
\hline 5 & 86,9 & 87 & 87,2 & 87 & 87,3 & 85,2 & \\
\hline 6 & 87,9 & 88,7 & 87,9 & 87,9 & 86,8 & 86,9 & \\
\hline 7 & 88,3 & 88,3 & 87,9 & 87,7 & 87,5 & 87,3 & \\
\hline 8 & 86,9 & 87,7 & 86,4 & 87,3 & 87,1 & 87,5 & \\
\hline 9 & 88,3 & 89,7 & 88 & 89 & 87,5 & 87,4 & \multirow{7}{*}{ 喜 } \\
\hline 10 & 88,9 & 88,3 & 88,8 & 88,3 & 85,5 & 86,9 & \\
\hline 11 & 87,4 & 87,9 & 88,5 & 88 & 87,9 & 87,1 & \\
\hline 12 & 87,3 & 88,4 & 86,9 & 88,5 & 87,3 & 86,9 & \\
\hline 13 & 89,5 & 89,8 & 89 & 87,9 & 87,2 & 86,8 & \\
\hline 14 & 90 & 90,3 & 89,3 & 87,8 & 86,6 & 86,2 & \\
\hline 15 & 88,9 & 89,7 & 89,8 & 88,5 & 87,3 & 87,7 & \\
\hline 16 & 89,7 & 88,6 & 90 & 89,8 & 86,8 & 87,5 & \multirow{7}{*}{ 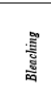 } \\
\hline 17 & 90,3 & 89,6 & 91,8 & 90 & 87,9 & 86,3 & \\
\hline 18 & 92,7 & 90,3 & 92,7 & 92 & 90 & 87,9 & \\
\hline 19 & 92,7 & 91,8 & 90,8 & 92,3 & 88 & 87,7 & \\
\hline 20 & 91 & 89,7 & 92 & 92,1 & 88,5 & 87 & \\
\hline 21 & 90 & 90,2 & 92,1 & 89,4 & 88,9 & 87,4 & \\
\hline 22 & 92 & 91,8 & 92 & 90,1 & 39 & 88,9 & \\
\hline 23 & 90,2 & 91 & 90,9 & 90 & 87,7 & 87,1 & \multirow{8}{*}{ 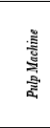 } \\
\hline 24 & 92 & 90,5 & 91 & 90,8 & 88,2 & 88 & \\
\hline 25 & 91,3 & 91,5 & 91 & 90,4 & 87,8 & 86,7 & \\
\hline 26 & 92,4 & 92,8 & 92,8 & 91 & 91 & 87,2 & \\
\hline 27 & 93,7 & 93,5 & 92,1 & 91,4 & 91,9 & 87,9 & \\
\hline 28 & 92,5 & 93 & 92,7 & 92 & 88,2 & 86,7 & \\
\hline 29 & 93 & 92,7 & 93,2 & 90,9 & 88,5 & 88 & \\
\hline 30 & 90,4 & 90 & 90,4 & 90,5 & 88 & 87,9 & \\
\hline
\end{tabular}


Pada pengukuran kebisingan hari ke-2, pengukuran dilakukan 30 titik pengukuran dengan rentang waktu yang telah ditentukan. Data pengukuran kebisingan pada hari ke-2 dapat dilihat pada Tabel 2.

Tabel 2. Hasil Pengukuran Kebisingan Hari Ke-2

\begin{tabular}{|c|c|c|c|c|c|c|c|}
\hline \multirow{3}{*}{ Titik } & \multicolumn{6}{|c|}{ Tingkat Kebisingan $(d B A)$} & \multirow{3}{*}{ Lolias } \\
\hline & \multicolumn{6}{|c|}{ Waktu } & \\
\hline & $09: 00$ & 11:00 & $13: 00$ & 15:00 & 17:00 & 21:00 & \\
\hline 1 & 86,3 & 85,2 & 86,9 & 87,6 & 85,4 & 86,3 & \multirow{8}{*}{ 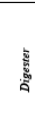 } \\
\hline 2 & 87,8 & 87,4 & 87,9 & 87,9 & 87,1 & 86,2 & \\
\hline 3 & 87,5 & 88 & 88,4 & 87,1 & 87 & 86 & \\
\hline 4 & 87,8 & 87,3 & 87 & 86,9 & 86,6 & 86,7 & \\
\hline 5 & 88 & 87 & 86,9 & 87,1 & 87,1 & 86,2 & \\
\hline 6 & 88,2 & 88,1 & 87,9 & 86,8 & 86,3 & 86,9 & \\
\hline 7 & 88,6 & 88 & 88,9 & 87 & 87 & 86,7 & \\
\hline 8 & 87,6 & 87,9 & 86,9 & 87 & 85,8 & 85 & \\
\hline 9 & 87 & 88 & 87,9 & 88,9 & 86,4 & 87,1 & \multirow{7}{*}{ 噌 } \\
\hline 10 & 87,9 & 89,1 & 88 & 89,3 & 86,9 & 88,4 & \\
\hline 11 & 88 & 87,9 & 87,9 & 87,9 & 85,2 & 87 & \\
\hline 12 & 87,9 & 88,2 & 87,5 & 87 & 87,7 & 86,2 & \\
\hline 13 & 88,1 & 88 & 87,9 & 86,3 & 89,6 & 84 & \\
\hline 14 & 87,9 & 88,7 & 87,1 & 88 & 87,8 & 86,9 & \\
\hline 15 & 89 & 88,9 & 89,3 & 89,1 & 87,9 & 88 & \\
\hline 16 & 90 & 91,3 & 90,2 & 90 & 86,3 & 86,3 & \multirow{7}{*}{ 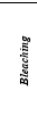 } \\
\hline 17 & 90,9 & 90,9 & 92 & 92,8 & 87,6 & 87 & \\
\hline 18 & 90 & 91,2 & 90,9 & 89 & 86,5 & 86,8 & \\
\hline 19 & 90,3 & 92,9 & 90,6 & 91,3 & 88,6 & 87,2 & \\
\hline 20 & 92,4 & 93 & 93 & 92,9 & 87 & 85,6 & \\
\hline 21 & 92,1 & 93 & 93,2 & 92 & 89,3 & 85,9 & \\
\hline 22 & 90 & 90,7 & 91 & 92,1 & $\begin{array}{l}86,6 \\
\end{array}$ & 87,6 & \\
\hline 23 & 90,3 & 91,2 & 92 & 92 & 87,9 & 86,8 & \multirow{8}{*}{$\begin{array}{l}\text { हूँ } \\
\text { है } \\
\text { है }\end{array}$} \\
\hline 24 & 91,9 & 92,2 & 92,7 & 92 & 88 & 88,2 & \\
\hline 25 & 92 & 93 & 93,8 & 92,8 & 87,9 & 86,2 & \\
\hline 26 & 93,2 & 91,9 & 93,8 & 93 & 89,4 & 88,9 & \\
\hline 27 & 91,9 & 92,8 & 92 & 92,8 & 85,9 & 89,4 & \\
\hline 28 & 92,3 & 90,9 & 91,8 & 91 & 88 & 88,9 & \\
\hline 29 & 92 & 92,9 & 92,7 & 91,1 & 89,9 & 88,6 & \\
\hline 30 & 91,2 & 91 & 91,1 & 91 & 89 & 89,2 & \\
\hline
\end{tabular}

Pada pengukuran kebisingan hari ke-3, pengukuran dilakukan 30 titik pengukuran dengan rentang waktu yang telah ditentukan. Data pengukuran kebisingan pada hari ke-3 dapat dilihat pada Tabel 3.

Tabel 3. Hasil Pengukuran Kebisingan Hari Ke-3

\begin{tabular}{|c|c|c|c|c|c|c|c|}
\hline \multirow{3}{*}{ Titik } & \multicolumn{6}{|c|}{ Tingkat Kebisingan $(d B A)$} & \multirow{3}{*}{ Lokiasi } \\
\hline & \multicolumn{6}{|c|}{ Waltu } & \\
\hline & 09:00 & 11:00 & 13:00 & 15:00 & $17: 00$ & $21: 00$ & \\
\hline 1 & 87,6 & 87,1 & 86,9 & 87,4 & 87,6 & 84,4 & \multirow{8}{*}{ 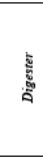 } \\
\hline 2 & 87,7 & 87,3 & 87,9 & 87 & 86,5 & 86,7 & \\
\hline 3 & 87 & 87,9 & 87 & 86,9 & 85,7 & 86,7 & \\
\hline 4 & 88,2 & 89 & 88 & 87,8 & 89,3 & 88,7 & \\
\hline 5 & 87,4 & 87,6 & 87,9 & 87,4 & 86,5 & 85 & \\
\hline 6 & 87,2 & 87,9 & 85,9 & 84,9 & 86,7 & 86,3 & \\
\hline 7 & 86,9 & 85,9 & 87,9 & 87 & 85,9 & 85,8 & \\
\hline 8 & 87,3 & 86,8 & 87,1 & 87 & 87,5 & 86,8 & \\
\hline 9 & 87,5 & 86,9 & 87,1 & 87 & 86,9 & 85,6 & \multirow{7}{*}{ : } \\
\hline 10 & 88 & 88,1 & 87,5 & 87,8 & 85 & 87,3 & \\
\hline 11 & 87,4 & 87 & 86,9 & 87,9 & 86,3 & 87 & \\
\hline 12 & 88 & 87,4 & 85,9 & 86 & 85,7 & 87,4 & \\
\hline 13 & 88,3 & 87,9 & 87,3 & 86,9 & 85,8 & 85,2 & \\
\hline 14 & 87,9 & 87 & 87,9 & 87,2 & 85,2 & 86,7 & \\
\hline 15 & 89,1 & 88,2 & 88 & 87,4 & 87,9 & 87 & \\
\hline 16 & 90 & 91,3 & 91,7 & 89 & 87 & 87,2 & \multirow{7}{*}{ 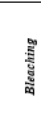 } \\
\hline 17 & 90,9 & 90,1 & 92 & 90 & 89,2 & 88,2 & \\
\hline 18 & 90 & 89,8 & 91,8 & 92 & 88,3 & 88,7 & \\
\hline 19 & 91 & 90,9 & 90,6 & 92 & 86,7 & 88,3 & \\
\hline 20 & 91,2 & 92 & 92 & 91,9 & 88,1 & 87,4 & \\
\hline 21 & 91,2 & 92,8 & 90,9 & 90,9 & 89,7 & 88,2 & \\
\hline 22 & 91,9 & 92,1 & 92 & 90,9 & 89,1 & $\begin{array}{l}80,2 \\
86,2\end{array}$ & \\
\hline 23 & 90 & 91,9 & 90,3 & 91,9 & 89 & 87,9 & \multirow{8}{*}{$\begin{array}{l}\text { हूँ } \\
\text { हूँ } \\
\text { हू. } \\
\text { हू. }\end{array}$} \\
\hline 24 & 91,3 & 91 & 90,9 & 91,3 & 89,6 & 89,4 & \\
\hline 25 & 92,9 & 93 & 93 & 92,5 & 89 & 88,9 & \\
\hline 26 & 91 & 90,9 & 90,3 & 91,9 & 89 & 88,6 & \\
\hline 27 & 91,3 & 92 & 92,4 & 91,9 & 89,6 & 89,2 & \\
\hline 28 & 92 & 93,1 & 92,4 & 92,3 & 90 & 89,4 & \\
\hline 29 & 93,2 & 92,9 & 93 & 93,2 & 90,9 & 90 & \\
\hline 30 & 90 & 90,4 & 90 & 91,1 & 89 & 88.6 & \\
\hline
\end{tabular}

Pada pengukuran kebisingan hari ke-4, pengukuran dilakukan 30 titik pengukuran dengan rentang waktu yang telah ditentukan. Data pengukuran kebisingan pada hari ke-4 dapat dilihat pada Tabel 4 . 
Tabel 4. Hasil Pengukuran Kebisingan Hari

Ke-4

\begin{tabular}{|c|c|c|c|c|c|c|c|}
\hline \multirow{3}{*}{ Titik } & \multicolumn{6}{|c|}{ Tingkat Kebisingan (dBA) } & \multirow{3}{*}{ Lolasi } \\
\hline & \multicolumn{6}{|c|}{ Waltu } & \\
\hline & 9:00 & 11:00 & 13:00 & $15: 00$ & $17: 00$ & $21: 00$ & \\
\hline 1 & 87,9 & 88,2 & 87,9 & 87,5 & 86,2 & 85,8 & \multirow{8}{*}{ 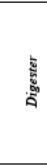 } \\
\hline 2 & 88,2 & 87,9 & 87 & 87,4 & 87,9 & 86,4 & \\
\hline 3 & 87,3 & 87,9 & 86,9 & 88 & 86,9 & 86,9 & \\
\hline 4 & 87,9 & 88,9 & 87,8 & 87 & 85,4 & 85,2 & \\
\hline 5 & 87,8 & 87,1 & 88,9 & 87,6 & 86,3 & 87,7 & \\
\hline 6 & 88 & 88,5 & 88,9 & 88,4 & 87 & 85,9 & \\
\hline 7 & 87,4 & 87,6 & 87,3 & 87,6 & 86,8 & 87,8 & \\
\hline 8 & 88,2 & 88 & 87,9 & 88,4 & 87,2 & 86,1 & \\
\hline 9 & 87,2 & 87,4 & 87,2 & 87,8 & 85,6 & 86,3 & \multirow{7}{*}{$\begin{array}{l}\text { है } \\
\text { है } \\
\text { है }\end{array}$} \\
\hline 10 & 88,1 & 89,6 & 88,6 & 87,9 & 85,9 & 87,6 & \\
\hline 11 & 87,9 & 88,8 & 87,9 & 87,5 & 87,9 & 86,5 & \\
\hline 12 & 88 & 87,4 & 87,8 & 87,9 & 86,2 & 88,6 & \\
\hline 13 & 87,9 & 88,7 & 87,9 & 89 & 89,7 & 87 & \\
\hline 14 & 89 & 88,9 & 89,4 & 89,4 & 89,7 & 89,3 & \\
\hline 15 & 89,7 & 89,5 & 89,9 & 88,7 & 89,2 & 86,6 & \\
\hline 16 & 90,8 & 91,2 & 91,8 & 91,2 & 88 & 88,2 & \multirow{7}{*}{ 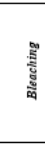 } \\
\hline 17 & 92 & 93,1 & 93,4 & 92,9 & 86,7 & 87,9 & \\
\hline 18 & 91,7 & 93,7 & 92,1 & 93 & 89,2 & 90 & \\
\hline 19 & 90 & 91,8 & 92,8 & 92,1 & 88,3 & 89,5 & \\
\hline 20 & 92,1 & 93 & 93,9 & 92,8 & 86,7 & 90,6 & \\
\hline 21 & 89,6 & 90,1 & 90,7 & 90 & 88,1 & 89,5 & \\
\hline 22 & 90,1 & 91 & 92,5 & 92,1 & 89,7 & 89,2 & \\
\hline 23 & 90,2 & 90,8 & 91,2 & 91,8 & 89,1 & 88 & \multirow{8}{*}{ 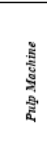 } \\
\hline 24 & 91,3 & 91,1 & 91,9 & 90,2 & 86,3 & 87,1 & \\
\hline 25 & 92,1 & 92,8 & 90,3 & 90 & 86,7 & 88,4 & \\
\hline 26 & 92 & 92,4 & 93,1 & 92,6 & 88,4 & 90,4 & \\
\hline 27 & 92,5 & 91 & 93,2 & 92,6 & 90,4 & 89,9 & \\
\hline 28 & 90,1 & 90,5 & 92,7 & 91,4 & 87,9 & 89,9 & \\
\hline 29 & 89,1 & 89,9 & 90,3 & 90,9 & 89,4 & 88,6 & \\
\hline 30 & 90,7 & 90,9 & 90,2 & 89 & 88,9 & 88,9 & \\
\hline
\end{tabular}

Pada pengukuran kebisingan hari ke-5, pengukuran dilakukan 30 titik pengukuran dengan rentang waktu yang telah ditentukan. Data pengukuran kebisingan pada hari ke-5 dapat dilihat pada Tabel 5 .

Tabel 5. Hasil Pengukuran Kebisingan Hari

Ke-5

\begin{tabular}{|c|c|c|c|c|c|c|c|}
\hline \multirow{3}{*}{ Titik } & \multicolumn{6}{|c|}{ Data Kebisingan Pada Hari Ke-5 } & \multirow{3}{*}{ Lokasi } \\
\hline & \multicolumn{6}{|c|}{ Waktu } & \\
\hline & $9: 00$ & $11: 00$ & $13: 00$ & $15: 00$ & $17: 00$ & $21: 00$ & \\
\hline 1 & 86,7 & 85,4 & 83,2 & 86,1 & 85,7 & 84,9 & \multirow{8}{*}{ हूँ } \\
\hline 2 & 88 & 87,7 & 88,5 & 89 & 88,4 & 86,2 & \\
\hline 3 & 87,9 & 87,9 & 86,9 & 85,5 & 87 & 86,9 & \\
\hline 4 & 88,3 & 87,9 & 88 & 87,9 & 86,2 & 86,7 & \\
\hline 5 & 87,9 & 88,2 & 87,6 & 87,8 & 84 & 84,3 & \\
\hline 6 & 88,1 & 88,2 & 87,9 & 87,4 & 86,9 & 87,5 & \\
\hline 7 & 87,2 & 88 & 87,3 & 87,9 & 85,4 & 85,6 & \\
\hline 8 & 87,9 & 88,2 & 88,4 & 88,9 & 86,3 & 86,8 & \\
\hline 9 & 88 & 87,7 & 87,9 & 86,7 & 87 & 87,3 & \multirow{7}{*}{ 劳 } \\
\hline 10 & 87,9 & 88,1 & 88,4 & 87,6 & 86,8 & 87 & \\
\hline 11 & 88 & 88,3 & 87,9 & 87 & 87,2 & 87,4 & \\
\hline 12 & 89,1 & 88,4 & 88,7 & 86,9 & 85,6 & 85,2 & \\
\hline 13 & 87,5 & 87,5 & 87,8 & 88,5 & 85,9 & 86,7 & \\
\hline 14 & 88,7 & 88,5 & 88 & 87,6 & 87,6 & 88 & \\
\hline 15 & 88,2 & 88,7 & 88,7 & 87,9 & 86,8 & 87,2 & \\
\hline 16 & 90,3 & 91,7 & 92 & 90 & 87,9 & 88,2 & \multirow{7}{*}{ हूँ } \\
\hline 17 & 92,1 & 93,8 & 92 & 92 & 88,4 & 88,7 & \\
\hline 18 & 92,5 & 93,5 & 90,8 & 90,8 & 88 & 88,5 & \\
\hline 19 & 92 & 90,8 & 89,4 & 93,1 & 88,2 & 87,1 & \\
\hline 20 & 90,9 & 90 & 89 & 93 & 88,6 & 88,4 & \\
\hline 21 & 91,5 & 93 & 92,6 & 91,2 & 89,4 & 87 & \\
\hline 22 & 90 & 90,3 & 90,9 & 90,2 & 89,6 & 86,2 & \\
\hline 23 & 92,8 & 93 & 93,9 & 92,8 & 87,8 & 89,2 & \multirow{8}{*}{ 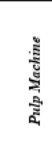 } \\
\hline 24 & 90,3 & 90,6 & 91,9 & 90,9 & 89,8 & 89,9 & \\
\hline 25 & 90 & 89,9 & 90,8 & 90,4 & 88 & 87,6 & \\
\hline 26 & 90,2 & 89,9 & 90,9 & 90,8 & 91,2 & 89,9 & \\
\hline 27 & 93,6 & 93 & 93,5 & 93,2 & 91,3 & 91,9 & \\
\hline 28 & 92,3 & 92,9 & 89,7 & 89,6 & 87,9 & 85,9 & \\
\hline 29 & 91,4 & 90,8 & 90,4 & 90,3 & 89,4 & 87,6 & \\
\hline 30 & 90,4 & 90,5 & 90,1 & 91 & 88,9 & 86,8 & \\
\hline
\end{tabular}


Pernyataan tingkat kebisingan siang hari merupakan model tingkat kebisingan equivalent yang dipergunakan untuk menyatakan tingkat kebisingan pada siang hari. Sesuai ketentuan dari menteri negara lingkungan hidup, data tingkat kebisingan ekuivalen pada setiap titik dan waktu diklasifikasi dalam 2 jenis, yakni tingkat kebisingan siang hari dan malam hari. Interval waktu sesuai peraturan KEP48/MENLH/11/1996 dengan waktu pengukuran dilakukan selama aktifitas 24 jam (LSM) dengan cara pada siang hari tingkat aktifitas yang paling tinggi selama 16 jam (LS) pada selang waktu 06.00-22.00. Tingkat kebisingan yang mewakili waktu siang hari diperoleh dari pengukuran kebisingan pada jam 09:00, 11:00, 13:00, 15:00, 17:00 dan 21:00.

Dari data yang diperoleh, tingkat kebisingan siang hari pada pada hari ke-1 dengan titik pengukuran ke 1 adalah sebagai berikut:

$\mathrm{L}_{1}=87,9 d B A \mathrm{~L}_{3}=88,5 d B A \mathrm{~L}_{5}=86,4 d B A$

$\mathrm{L}_{2}=88 \mathrm{dBA} \mathrm{L}_{4}=87,8 \mathrm{dBA} \mathrm{L}_{6}=85,1 \mathrm{dBA}$

Maka dengan formula 2.1, diperoleh hasil perhitungan sebagai berikut:

$$
\begin{aligned}
& L s=10 \log \left\{f_{1} 10^{0.1 L_{1}}+f_{2} 10^{0.1 L_{2}}+\ldots \ldots f_{n} 10^{0.1 L_{n}}\right\} d B A \\
& L s=10 \log \left\{\frac{2}{16} \cdot 10^{0.1879}+\frac{2}{16} \cdot 10^{0.2888}+\frac{2}{16} \cdot 10^{0.12885}+\frac{2}{16} \cdot 10^{0.18778}+\frac{4}{16} \cdot 10^{0.12864}+\frac{2}{16} \cdot 10^{0.12851}\right\} \\
& L s=10 \log \left\{\frac{2}{16} \cdot 10^{879}+\frac{2}{16} \cdot 10^{8.8}+\frac{2}{16} \cdot 10^{8.85}+\frac{2}{16} \cdot 10^{877}+\frac{4}{16} \cdot 10^{8.64}+\frac{2}{16} \cdot 10^{851}\right\} d B A \\
& L s=10 \log \{469335379,8\} d B A \\
& L s=86,71 d B A
\end{aligned}
$$

Nilai Ls pada titik ke 1 adalah 86,71 $d B A$. Perhitungan yang sama dilakukan untuk titik ke 2 sampai ke titik 30. Nilai Ls pada titik ke 2 adalah 87,20 $d B A$. Rekapitulasi tingkat kebisingan Ls pada hari ke-1 untuk setiap titik pengukuran dapat dilihat pada Tabel 4.6.

Tabel 6.Rekapitulasi Tingkat Kebisingan Siang pada Hari Ke-1

\begin{tabular}{cccc}
\hline $\begin{array}{c}\text { Titik } \\
\text { Pengukuran }\end{array}$ & LS (dBA) & $\begin{array}{c}\text { Titik } \\
\text { Pengukuran }\end{array}$ & LS $(\boldsymbol{d B} \boldsymbol{A})$ \\
\hline 1 & 86,71 & 16 & 88,07 \\
2 & 87,20 & 17 & 88,86 \\
3 & 87,03 & 18 & 90,51 \\
4 & 87,00 & 19 & 90,07 \\
5 & 86,31 & 20 & 89,61 \\
6 & 87,03 & 21 & 89,19 \\
7 & 87,22 & 22 & 90,04 \\
8 & 86,58 & 23 & 88,91 \\
9 & 87,70 & 24 & 89,49 \\
10 & 87,08 & 25 & 89,29 \\
11 & 87,25 & 26 & 90,90 \\
12 & 86,98 & 27 & 91,50 \\
13 & 87,77 & 28 & 90,52 \\
14 & 87,83 & 29 & 90,62 \\
15 & 87,99 & 30 & 88,89 \\
\hline Sumber: Pengolahan data & &
\end{tabular}


Total tingkat kebisingan siang hari pada hari ke-1 dibandingkan dengan Nilai Ambang Batas (NAB) yang ditetapkan oleh pemerintah Kep51/MEN/1999 yaitu 85 dB. Selisih tingkat kebisingan yang akan direduksi dapat dilihat pada Tabel 7.

Tabel 7. Tingkat Kebisingan Siang pada Hari Ke-1 yang Direduksi

\begin{tabular}{cccccccc}
\hline Titik & $\begin{array}{c}\mathbf{L S} \\
(\boldsymbol{d} \boldsymbol{B} \boldsymbol{A})\end{array}$ & $\begin{array}{c}\text { NAB } \\
(\boldsymbol{d} \boldsymbol{B} \boldsymbol{A})\end{array}$ & $\begin{array}{c}\text { Reduksi } \\
(\boldsymbol{d} \boldsymbol{B} \boldsymbol{A})\end{array}$ & Titik & $\begin{array}{c}\text { LS } \\
(\boldsymbol{d B \boldsymbol { A }})\end{array}$ & $\begin{array}{c}\text { NAB } \\
(\boldsymbol{d} \boldsymbol{B} \boldsymbol{A})\end{array}$ & $\begin{array}{c}\text { Reduksi } \\
(\boldsymbol{d} \boldsymbol{B} \boldsymbol{A})\end{array}$ \\
\hline 1 & 86,71 & 85 & 1,71 & 16 & 88,07 & 85 & 3,07 \\
2 & 87,20 & 85 & 2,20 & 17 & 88,86 & 85 & 3,86 \\
3 & 87,03 & 85 & 2,03 & 18 & 90,51 & 85 & 5,51 \\
4 & 87,00 & 85 & 2,00 & 19 & 90,07 & 85 & 5,07 \\
5 & 86,31 & 85 & 1,31 & 20 & 89,61 & 85 & 4,61 \\
6 & 87,03 & 85 & 2,03 & 21 & 89,19 & 85 & 4,19 \\
7 & 87,22 & 85 & 2,22 & 22 & 90,04 & 85 & 5,04 \\
8 & 86,58 & 85 & 1,58 & 23 & 88,91 & 85 & 3,91 \\
9 & 87,70 & 85 & 2,70 & 24 & 89,49 & 85 & 4,49 \\
10 & 87,08 & 85 & 2,08 & 25 & 89,29 & 85 & 4,29 \\
11 & 87,25 & 85 & 2,25 & 26 & 90,90 & 85 & 5,90 \\
12 & 86,98 & 85 & 1,98 & 27 & 91,50 & 85 & 6,50 \\
13 & 87,77 & 85 & 2,77 & 28 & 90,52 & 85 & 5,52 \\
14 & 87,83 & 85 & 2,83 & 29 & 90,62 & 85 & 5,62 \\
15 & 87,99 & 85 & 2,99 & 30 & 88,89 & 85 & 3,89 \\
\hline Sumber: Pengolahan data & & & & &
\end{tabular}

Perbandingan antara tingkat kebisingan siang hari dengan Nilai Ambang Batas (NAB) yang ditetapkan oleh pemerintah Kep-51/MEN/1999 dapat dilihat pada Gambar 1.

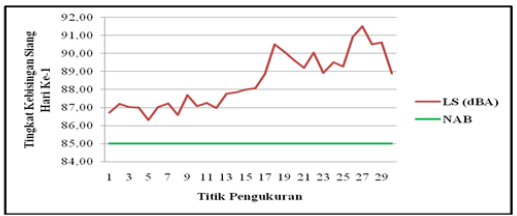

Gambar 1. Perbandingan antara Ls hari ke-1dengan (NAB)

Berdasarkan perhitungan Ls dari hari ke-1 sampai hari ke-5 dapat dilihat pada Tabel 8.

Tabel 8. Tingkat Kebisingan dari Hari Ke-1 Sampai Hari Ke-5

\begin{tabular}{|c|c|c|c|c|c|}
\hline \multirow[b]{2}{*}{$\begin{array}{c}\text { Titik } \\
\text { Pengukuran }\end{array}$} & \multicolumn{5}{|c|}{$\mathrm{LS}(d B A)$} \\
\hline & Hari Ke- & Hari Ke- & $\underset{3}{\mathrm{HariKe}}$ & Hari Ke- & $\underset{5}{\text { Hari Ke- }}$ \\
\hline 1 & 86,71 & 85,66 & 86,48 & 86,62 & 84,92 \\
\hline 2 & 87,20 & 86,80 & 86,54 & 86,99 & 87,52 \\
\hline 3 & 87,03 & 86,77 & 86,18 & 86,70 & 86,50 \\
\hline 4 & 87,00 & 86,43 & 88,07 & 86,44 & 86,81 \\
\hline 5 & 86,31 & 86,50 & 86,41 & 86,89 & 86,06 \\
\hline 6 & 87,03 & 86,70 & 86,02 & 87,20 & 87,01 \\
\hline 7 & 87,22 & 87,10 & 85,96 & 86,76 & 86,24 \\
\hline 8 & 86,58 & 86,10 & 86,57 & 87,05 & 87,07 \\
\hline 9 & 87,70 & 86,89 & 86,30 & 86,23 & 86,82 \\
\hline 10 & 87,08 & 87,58 & 86,55 & 87,26 & 86,98 \\
\hline 11 & 87,25 & 86,59 & 86,42 & 87,24 & 87,02 \\
\hline 12 & 86,98 & 86,92 & 86,10 & 86,94 & 86,76 \\
\hline 13 & 87,77 & 87,40 & 86,30 & 88,08 & 86,63 \\
\hline & 87,83 & 87,20 & 86,27 & 88,77 & 87,44 \\
\hline \multirow{2}{*}{\multicolumn{6}{|c|}{ Tabel 4.16 Tingkat Kebisingan dari Hari Ke-1 Sampai Hari Ke-5 (Lanjutan) }} \\
\hline 15 & 87,99 & 88,04 & & & 87,24 \\
\hline 16 & 88,07 & 88,51 & 88,86 & 89,59 & 89,44 \\
\hline 17 & 88,86 & 89,78 & 89,52 & 90,66 & 90,66 \\
\hline 18 & 90,51 & 88,54 & 89,51 & 91,01 & 90,21 \\
\hline 19 & 90,07 & 89,72 & 89,32 & 90,15 & 89,74 \\
\hline 20 & 89,61 & 90,53 & 89,93 & 91,00 & 89,52 \\
\hline 21 & 89,19 & 90,69 & 90,11 & 88,96 & 90,41 \\
\hline 22 & 90,04 & 89,13 & 90,02 & 90,20 & 89,16 \\
\hline 23 & 88,91 & 89,59 & 89,65 & 89,62 & 91,10 \\
\hline 24 & 89,49 & 90,30 & 89,94 & 89,16 & 89,94 \\
\hline 25 & 89,29 & 90,76 & 91,01 & 89,56 & 88,83 \\
\hline 26 & 90,90 & 91,20 & 89,67 & 90,82 & 90,04 \\
\hline 27 & 91,50 & 90,31 & 90,45 & 91,02 & 92,06 \\
\hline 28 & 90,52 & 89,86 & 90,94 & 89,78 & 89,49 \\
\hline 29 & 90,62 & 90,68 & 91,61 & 89,14 & 89,46 \\
\hline 30 & 88.89 & 89,75 & 89.23 & 89.15 & 89,12 \\
\hline
\end{tabular}


Berdasarkan data tingkat kebisingan dilakukan pemetaan kebisingan dengan software surfer 8.0pada setiap titik pengukuran. Hasil pemetaan Ls dari hari ke-1 sampai hari ke-5 dapat dilihat pada Gambar 2.

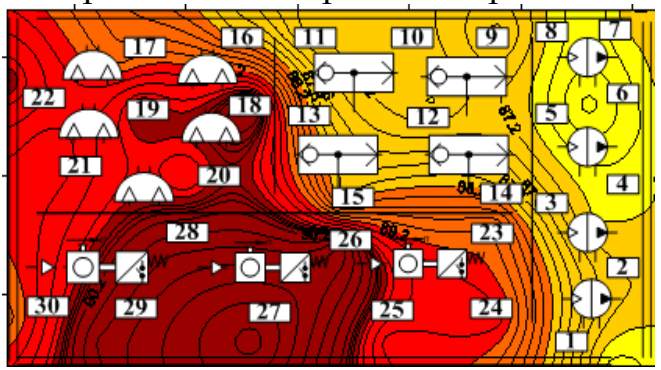

Gambar 2.Peta tingkat kebisingan (noise mapping)ls pada hari ke-1 dengan software surfer 8.0

\section{KESIMPULAN}

Berdasarkan hasil pengolahan data dan analisis yang telah dilakukan sebelumnya maka dapat diambil kesimpulan bahwa tingkat kebisingan berpengaruh terhadap kelelahan kerja dengan hubungan semakin tinggi tingkat kebisingan maka semakin meningkat kelelahan. Pengaruh yang ditimbulkan dari kebisingan dapat dilihat dari tingkat kelelahan responden yang sebagian besar mengalami kelelahan sedang dan kelelahan berat. Ini menunjukan bahwa tingkat kebisingan dapat mengganggu kesehatan para tenaga kerja yang bekerja pada bagian fiberline terutama di area pulp machine. Skor yang paling tinggi dari 30 pertanyaan adalah pada pertanyaan pertama dengan skor sebesar 46 dari 30 responden. Adapun keluhan yang dirasakan adalah merasakan berat di kepala setelah bekerja. Ini menunjukkan bahwa kelelahan yang sering dialami oleh responden adalah merasakan berat di kepala setelah bekerja.

\section{DAFTAR PUSTAKA}

Buchari, 2007. Kebisingan dan Hearing Conversation Program.

Departermen Tenaga Kerja RI, 1999. Keputusan Menteri Tenaga Kerja

No.51/MEN/1999 Tentang Nilai Ambang Batas Faktor Fisik di Tempat Kerja. Jakarta: Depnaker RI.

Efendi, Arifin Nur, 2013. Pengaruh Kebisingan Terhadap Kelelahan pada Tenaga Kerja Bagian Produksi "Candy" PT. Deltomed Laboratories Wonogiri, Jurnal Fakultas Ilmu Kesehatan, Universitas Muhamadiyah Surakarta, Surakarta. 
Harinaldi, Prinsip-Prinsip Statistik Untuk Teknik Dan Sains, Jilid 1, Jakarta, Penerbit: Erlangga, 2005.

Hidayah, Lailatul Fitri, 2011. Pengaruh Kebisingan Terhadap Kelelahan Tenaga Kerja di Bagian Mesin Tenun PT. Iskandartex Surakarta, Skripsi Fakultas Kedokteran Universitas Sebelas Maret, Surakarta.

Isnarningsih, Ema., 2009. Pengaruh Intensitas Kebisingan Terhadap Kelelahan Tenaga Kerja Di Bagian Welding $2 b$ dan Bagian P2 Shipping Cbu Di Pt X Plant Ii Jakarta Utara, Skirpsi Fakultas Kedokteran Universitas Sebelas Maret, Surakarta.

Krisnawati, Bayu., 2010. Hubungan Intensitas Kebisingan Terhadap Kelelahan Kerja Sebelum dan Sesudah Kerja pada Karyawan Mekanik Maintenancw Utility Compresor Di PT. Indo Acidatama, Tbk. Kemiri Kebakkramat Karangyar, Skipsi Fakultas Kedokteran Universitas Sebelas Maret, Surakarta.

Noviani, Risa Diah., 2010. Pengaruh Intensitas Kebisingan Terhadap Stres Kerja pada Tenaga Kerja Penggilingan Padi Di Kecamatan Mojolaban Sukoharjo, Jurnal Fakultas Kedokteran Universitas Sebelas Maret, Surakarta.

Prabu, 2008. Dampak Kebisingan Terhadap Kesehatan.

Sari, Ratih Perwita., 2010. Pengaruh Intensitas Kebisingan Terhadap Kelelahan Kerja Pada Tenaga Kerja Bagian Screening Cv. Mekar Sari Wonosari Klaten, Jurnal Fakultas Kedokteran Universitas Sebelas Maret, Surakarta.

Saputra, Ade, dkk, 2015. Pemetaan Tingkat Kebisingan Yang Ditimbulkan Oleh Mesin Pengolahan Kelapa Sawit Di PT. Tasma Puja, Kabupaten Kampar-Riau. JOM FMIPA. Volume 2.

Sihar, Tigor Benjamin Tambunan, 2005. Kebisingan di Tempat Kerja (Occupational Noise), Yogyakarta, Andi.

Sukmono, Daniel Haris., 2010. Pengaruh Kebisingan Terhadap Tingkat Kelelahan Kerja Di Penggilingan Padi Desa Griyan Keluran Baturan kecamatan Colomadu Kab.Karangnyar, JurnalFakultas Kedokteran Universitas Sebelas Maret, Surakarta.

Wardani, Tyas Lilia, 2010. Penagaruh Intensitas Kebisingan Terhadap Kelelahan Kerja Pada Tenaga Kerja Penggilingan Padi Di Kecamatan Mojolaban Sukoharjo, Skripsi Fakultas Kedokteran Universitas Sebelas Maret, Surakarta. 